\title{
Pembaharuan Sistem Pendidikan Islam di Indonesia (Menggagas Format Pendidikan Islam Ideal di Tengah Arus Perubahan)
}

\author{
Ali Murtadlo M.S. \\ Dosen Fakultas Tarbiyah IAIN Sulthan Thaha Saifuddin Jambi
}

\begin{abstract}
This paper reveals some poor elements in the Indonesian education. There are several structures and systems in education that need to be updated. If this condition is left just like that, then education will not lead to the transformation of the intellect which is expected to advance the nation. Dichotomy in education, and lack of ability of teachers, are elements that need to be observed. Moreover, the ideal Islamic educational system improvement needs to be done, namely with integralistic education, humanistic, pragmatic, and rooted in a strong culture. The system needs to be refreshed to get composition of the ideal of education to transform the concepts and implementation knowledge. However, the need to also understand the performance of the basic philosophical framework of Islamic teachings for a change with a definite direction. Therefore, education can be relevant to the needs of society in turmoil facing science and sophisticated technology.
\end{abstract}

Keywords: Education, System, Islam, Indonesia, Change, and Society.

\section{Pendahuluan}

Menggagas soal pendidikan adalah menggagas soal kebudayaan dan peradaban manusia. Gagasan-gagasan tentang pendidikan itu akan merambah masuk secara dinamis kepada wilayah pembentukan peradaban manusia di masa depan. Hal ini lebih disebabkan pendidikan merupakan upaya umat manusia untuk merekonstruksi pengalaman-pengalaman peradabannya di masa lalu secara berkelanjutan guna memenuhi tugas kehidupannya dalam meraih kebudayaan dan peradaban masa depan yang lebih baik. Dengan kata lain, pendidikan merupakan sebuah sistem dan cara meningkatkan kualitas hidup manusia dalam segala aspek kehidupannya. 
Dalam sejarah, sekalipun dalam masyarakat yang masih terbelakang (primitif, hampir tidak ada kelompok manusia yang tidak menggunakan pendidikan sebagai alat pembudayaan dan peningkatan kualitasnya), pendidikan dijadikan sebagai usaha sadar yang dibutuhkan untuk menyiapkan anak manusia demi menunjang perannya dalam dinamika perubahan kebudayaan masyarakat di masa yang akan datang. Karena itu, upaya pendidikan yang dilakukan oleh suatu bangsa tentu memiliki hubungan yang sangat signifikan dengan blue print peradaban bangsa itu di masa mendatang. Upaya ini menunjukkan bahwa pendidikan merupakan salah satu kebutuhan asasi manusia. Lebih jauh dari itu, Mohammad Natsir pernah menegaskan bahwa pendidikan merupakan salah satu faktor yang ikut menentukan maju mundurnya kehidupan masyarakat tersebut. ${ }^{1}$ Pernyataan Natsir ini menunjukkan bahwa pendidikan memegang peran yang sangat vital dalam bagi menentukan maju mundurnya kehidupan manusia. Pendidikan menjadi pemicu masyarakat untuk meningkatkan kualitasnya dalam segala aspek kehidupan demi mencapai kemajuan. Tujuan untuk menjunjung perannya di masa datang. Hal ini terbukti dalam kehidupan sekarang pendidikan tampil dengan daya pengaruh yang sangat besar dan menjadi variabel pokok masa depan manusia.

Perubahan peradaban dan kebudayaan masyarakat berjalan secara cepat dan berkelindan. Perubahan ini tentu saja akan mempengaruhi pilihan masyarakat terhadap pendidikan sebagai agent of change. Pendidikan yang akan dipilih masyarakat sudah barang tentu yang dapat mengembangkan kualitas dirinya sesuai dengan perkembangan perubahan itu. Sebaliknya, pendidikan yang kurang memberikan janji masa depan tidak akan mengundung minat atau antusiasme masyarakat. Sesuai dengan ciri masyarakat seperti ini, maka pendidikan yang akan dipilihnya adalah pendidikan yang dapat memberikan kemampuan secara teknologis fungsional, individual, informatif, dan terbuka. Adapun yang lebih penting lagi, kemampuan secara etika dan moral yang dapat dikembangkan melalui agama.

Dalam konteks inilah akan dijumpai betapa pendidikan Islam-yang dari segi kuantitas menunjukkan perkembangan yang dinamis mulai dari taman kanak-kanak sampai pergunan tinggi-menghadapi berbagai persoalan. Tidak saja pada persoalan tataran normatif-filosofis, tetapi juga menyangkut orientasi 
kultural di masa depan. Rangkaian persoalan itu tidak dapat dipisahkan, karena terdapat kaitan yang bersifat causal relationship. Karena itu, langkah penyelesaiannya harus bersifat menyeluruh dan tidak bisa dengan cara parsial atau kasuistik.

\section{Dinamika Masyarakat: Pergeseran Pandangan terhadap Pendidikan}

Secara umum, perubahan dipahami sebagai terjadinya perubahan di semua sektor kehidupan masyarakat. Perubahan dapat terjadi di bidang norma-norma, nilai-nilai, pola-pola perilaku, organisasi, susunan dan stratifikasi kemasyarakatan serta lembaga kemasyarakatan. ${ }^{2}$ Dalam kajian teoritik seringkali diperdebatkan, apakah perubahan atau dinamika dalam masyarakat merupakan perubahan budaya (adtural change) atau perubahan sosial (social change). Pertama, berkaitan dengan perubahan yang berhubungan dengan ide-ide dan nilai-nilai yang dianut oleh kelompok masyarakat; dan kedua, berkaitan dengan perubahan di bidang pola hubungan dalam masyarakat dan perkembangan kelembagaannya. Kedua perubahan itu mempunyai hubungan timbal balik.

Dipandang dari perspektif fungsional, pendidikan dituntut melakukan penyesuaian terus-menerus dengan perkembangan masyarakat. Selain itu, pendidikan juga harus memainkan peran yang terarah sejalan dengan karakteristiknya selaku institusi teleologis. Disinilah dituntut kemampuan proyektif dari pendidikan dalam menangkap kecenderungan yang akan terjadi di masa depan. ${ }^{3}$ Berkaitan dengan kemampuan proyektif ini, yang sering ditangkap dengan jelas dalam masyarakat akhir-akhir ini adalah adanya pergeseran pandangan terhadap pendidikan seiring dengan tuntutan masyarakat (scrial demend) yang berkembang dalam skala yang lebih makro. Kini, masyarakat melihat pendidikan tidak lagi dipandang hanya sebagai bentuk pemenuhan kebutuhan terhadap perolehan pengetahuan dan keterampilan dalam konteks waktu sekarang.

Di sisi lain, pendidikan dipandang sebagai bentuk investasi, baik modal maupun manusia (buman and capital imedtmen) untuk membantu meningkatkan keterampilan dan pengetahuan sekaligus mempunyai kemampuan produktif dimasa depan yang diukur dari tingkat penghasilan yang diperolehnya. ${ }^{4}$ Karena 
itu, tidak mengherankan apabila pendidikan selahu dipertimbangkan nilai imbalannya (rule of return), berapa besar investasi serta keuntungan atau efektivitas yang akan diperolehnya. Pertimbangan demikian tampaknya tidak hanya berlaku dalam kebijakan ekonomi makro suatu negara, tetapi sudah berlaku secara universal dalam masyarakat. Karenanya, wajar saja apabila saat ini masyarakat sudah mulai selektif dalam memilih lembaga pendidikan dari tingkat taman kanak-kanak sampai perguruan tinggi. Perubahan demikian merupakan akibat dari rangkaian perubahan yang terjadi dalam skala makro. Perubahan yang terjadi di dalam masyarakat dalam bidang yang lain mempengaruhi pula pandangan dan pilihan masyarakat terhadap pendidikan. Inilah yang disebut masyarakat sebagai kesatuan sistem.

Dalam kajian sosiologis digambarkan, bahwa perubahan tersebut bersifat universal (universal change) yang meliputi berbagai aspek kehidupan manusia. Dan bahkan berjalan secara revolutif seperti terjadinya revolusi di bidang teknologi, komunikasi, pendidikan, dan media massa. ${ }^{5}$ Terjadinya revolusi ini secara sistematis berpengaruh terhadap ide, norma, perilaku, hubungan sosial dan kelembagaan dalam masyarakat dengan corak dan cirinya yang lebih baru.

Ahmad Watik Pratiknya ${ }^{6}$ lebih jelas menggambarkan corak dan ciri-ciri masyarakat yang akan berkembang di masa sekarang dan masa yang akan datang. Pertama, terjadinya teknologisasi kehidupan sebagai akibat adanya loncatan revolusi di bidang ilmu pengetahuan dan tekonologi. Masyarakat teknologis ditandai dengan adanya pembakuan kerja dan perubahan nilai, yaitu makin dominannya pertimbangan efisiensi dan produktivitas.

Kedva, kecenderungan perilaku masyarakat yang semakin fungsional. Dalam masyarakat seperti ini hubungan sosial hanya dilihat dari sudut kegunaan dan kepentingan semata. Keberadaan seseorang sangat ditentukan sejauhmana ia fungsional bagiorang lain. Karena itu, kemampuan seseorang secara individual sangat dibutuhkan. Dalam masyarakat seperti itu, terjadi pergeseran pola hubungan sosial dari "affective" ke "effective netural", sebagaimana dikatakan oleh Parson, yakni perubahan dari hubungan yang mempribadi dan emosional ke hubungan yang tidak mempribadi dan berjarak.

Ketiga, masyarakat padat informasi. Dalam masyarakat seperti ini, keberadaan seseorang sangat ditentukan oleh berapa banyak dan sejauh mana ia 
menguasai informasi. Keempat, kehidupan yang makin sistemik dan terbuka, yakni masyarakat yang sepenuhnya berjalan dan diatur oleh sistem yang terbuka (open system).

\section{Kondisi Pendidikan di Indonesia di Tengah Arus Perubahan}

Mencermati kondisi pendidikan di Indonesia dewasa ini, membawa kepada kesadaran bahwa sebenarnya telah banyak dilakukan berbagai pembaruan di berbagai bidang. Hanya saja, tujuan pembanuan itu pada akhirnya adalah sebatas "untuk menjaga agar produk pendidikan kita tetap relevan dengan kebutuhan dunia kerja atau persyaratan bagi pendidikan lanjut pada jenjang pendidikan berikutnya., ${ }^{17} \mathrm{Hal}$ itu karena pendidikan nasional terperangkap di dalam sistem kehidupan yang operatif sehingga telah terkungkung di dalam paradigmaparadigma yang tunduk kepada kekuasaan. ${ }^{8}$ Era rezim Orde Baru yang otoriter telah melahirkan sistem penilidikan yang tidak mampu melakukan pemberdayaan masyarakat secara efektif; kendatipun secara jujur kita juga harus mengakui bahwa rezim ini memang telah mampu menunjukkan prestasinya yang cukup baik di bidang pendidikan berupa kemajuan-kemajuan pendidikan secara kuantitatif, mulai dari taman kanak-kanak sampai perguruan tinggi.

Pendidikan pada masa Orde Baru memilikiempat ciriutama. Pertama, sistem yang kaku dan sentralistik, yang terperangkap di dalam kekuasaan otoritas pasti dan sistem birokrasi yang kaku sifatnya. Ciri ini tidak hanya menyebabkan terbunuhnya kreativitas dan potensi anak didik khususnya, tetapi juga tenggelamnya pluralitas budaya lokal. Kedua, sistem pendidikan nasional di dalam pelaksanaannya telah diracuni oleh unsur-unsur korupsi, kolusi, nepotisme $(\mathrm{KKN})$ dan koncoisme (cronyism). Akibatnya, sistem pendidikan tidak mengutamakan kualitas, tetapi mementingkan kepentingan pribadi maupun kelompok. Ketiga, sistem pendidikan tidak berorientasi pada pemberdayaan masyarakat sehingga tujuan pendidikan untuk mencerdaskan kehidupan bangsa, sebagaimana diamanatkan dalam Pembukaan UUD 1945, telah sirna dan diganti dengan praktik-praktik "memberatkan" rakyat untuk memperoleh pendidikan yang berkualitas. ${ }^{9}$ Kemprat, pada kenyataannya sistem pendidikan sekarang ini belum sanggup mengantisipasi masa depan; belum mampu menyiapkan output yang sesuai dengan permintaan dasar dan kondisi riil perubahan masyarakat, 
kurang memiliki kemampuan bersaing secara komperitif dan kreatif dan hanya sekadar mengandalkan ijazah resmi dari bidang studi dan dari suatu lembaga pendidikan tertentu dengan kemampuan yang sangat terbatas.

Secara umum, kondisi pendidikan Islam di Indonesia, juga menghadapi nasib yang sama dengan pendidikan nasional. Kualitas lembaga pendidikan Islam secara umum masih menyedihkan. Meskipun telah ada beberapa madrasah yang sudah mampu mengungguli kualitas sekolah umum, tetapi secara umum kualitas madrasah dan sekolah-sekolah serta perguruan tinggi Islam masih belum memadai. Citra lembaga pendidikan Islam rendah. Hal ini bisa dilihat pada nilai ujian akhir yang lebih rendah daripada sekolah negeri dan swasta lainnya. ${ }^{10}$

Secara lebih khusus, pendidikan Islam mengadapi berbagai persoalan dan kesenjangan dalam berbagai aspek yang lebih kompleks daripada pendidikan nasional, yaitu berupa dikotomi pendidikan, kurikulum, tujuan, sumber daya, serta manajemen pendidikan Islam. Kelemahan juga terlihat pada kualitas dan kuantitas guru yang masih belum memadai. Guru adalah kunci keberhasilan sekolah. Jika gurunya berkualitas rendah dan rasio guru tidak memadai, maka output pendidikan dengan dengan sendirinya akan rendah. Gaij guru secara umum masih kecil. Tidak sedikit guru madrasah swasta gajinya di bawah upah minimum regional (UMR). Latar belakang siswa lembaga pendidikan Islam pada umumnya dari kelas menengah ke bawah.

Memperharikan berbagai kelemahan pendidikan Islam di atas, tampaknya pendidikan Islam menghadapi tantangan yang begitu kompleks, baik internal maupun dosternal. Tantangan internal yang dihadapi menyangkut sisi penajdikan Ilam setugai program pendidikan, yaitu persoalan dikotomi pendidikan, orientasi, dan pendidikan Islam yang kurang tepat. Sempitnya pemahaman terhadap esensi ajaran Islam, perencanaan dan penyusunan materi, metodologi dan evaluasi yang kurang tepat, pelaksanaan dan penyelenggaraan pendidikan Islam yang masih bersikap ekslusif, dan belum mampu berinteraksi dan berkomunikasi dengan lainnya. Tantangan eksternal yang dihadapi berupa kemajuan ilmu pengetahuan dan teknologi yang berdampak pada munculnya scientific critism terhadap pelajaran agama yang bersifat konservatif, tradisional, tekstual dan skriptual. Tantangan pada era globalisasi di bidang informasi, 
perubahan sosial ekonomi dan budaya dengan seala dampaknya, kemajemukan masyarakat yang beragam yang masih belum siap untuk berbeda paham dan justru cenderung bersifat apologis, fanatik, absolutis, serta truth claim yang dibungkus dengan simpul-simpul kepentingan, baik pribadi, politik, maupun sosiologis. ${ }^{11}$

Adanya tantangan eksternal tersebut membuat semakin sadar dan harus mengakui dengan jujur bahwa pendidikan Islam hingga saat ini kelihatan sering terlambat merumuskan diri untuk merespon perubahan dan kecenderungan perkembangan masyarakat sekarang dan masa yang akan datang. Sistem pendidikan Islam kebanyakan masih mengorientasikan diri pada bidang humaniora dan sosial ketimbang ilmu-ilmu eksakta semacam fisika, kimia, biologi, dan matematika modem. Padahal, keempat bidang ilmu tersebut mutlak diperlukan dalam pengembangan teknologi. Ilmu-ilmu eksakta belum mendapar apresiasi dan tempat yang sepatutnya dalam pendidikan Islam. ${ }^{12}$

Di sisilain, kondisi pendidikan sekarang ini berada pada posisi determinasi historis dan realisme. Pada sejarah awal pendidikan Islam pernah mencapai kejayaan. Ketika itu, dunia Islam mampu melahirkan tokoh-tokoh pengetahuan berkaliber dunia. Akan tetapi, kondisi sekarang justru sebaliknya, pendidikan Islam seakan-akan tidak berdaya karena dihadapkan dengan realitas perkembangan ilmu pengetahuan dan teknologi. ${ }^{13}$ Dalam posisi yang sangat tergantung dengan peradaban industri modern, pendidikan Islam belum mampu mengintegrasikan ilmu sebagaimana idealisasinya. Hal ini "didukung" dengan sebagian umat Islam yang kurang meminati ilmu-ilmu umum, bahkan mengharamkan. Dalam kondisi ini, dikotomi masih sangat kuat dan pelaksanaan pendidikan Islam hanya mampu menyesuaikan diri dengan kecenderungan pendidikan yang lebih berorientasi materialis dalam segala aspeknya dan kondisi ini pun cukup diperparah dengan kuatnya kecenderungan sekularistik pada pendidikan Islam.

Menyadari pendidikan Islam sebagaimana pendidikan lainnya, ada berbagai usaha pembaruan dan peningkatan kualitas pendidikan Islam. Hanya saja usaha pembaruan dan peningkatan pendidikan Islam sering bersifat sepotongsepotong atau tidak komprehensif dan menyeluruh. Usaha peningkatan dan pembaharuan ini dilakukan sekenannya atau seingatnya, maka tidak terjadi 
perubahan esensial dalam sistem pendidikan Islam. Sistem pendidikan Islam tetap cenderung berorientasi ke masa silam, ketimbang berorientasi ke masa depan. Sebagian besar sistem pendidikan Islam juga belum dikelola secara profesional. ${ }^{16}$ Dengan kenyataan ini, sistem pendidikan Islam harus senantiasa mengorientasikan diri untuk mejawab kebutuhan dan tantangan yang muncul dalam masyarakat sebagai konsekuensi perubahan logis. ${ }^{13}$ Hanya dengan respon yang tepat, pendidikan Islam dapat diharapkan lebih fungsional dalam mempersiapkan anak didik untuk menjawab tantangan perkembangan Indonesia modern yang terus semakin kompleks. ${ }^{16}$

Kompleksitas tantangan itu dapat dilihat dari kenyataan bahwa berbarengan dengan semakin tingginya tuntutan penguasaan ilmu pengetahuan dan teknologi. Hal ini perlu disadari sebagai pemantapan dan penghayatan dalam pengalaman ajaran agama. Terjadinya akselerasi pembangunan yang menuntuk ilmu pengetahuan dan teknologi yang kian canggih, maka agama perlu menyantuni masyarakat yang menghadapi kegoncangan nilai atau "gegar budaya". Dalam konteks terakhir ini, terjadinya kebangkitan agama atau dengan istilah lcbih moderat, intensifikasi penghayatan dan pengalaman ajaran-ajaran agama.

Perkembangan ini tentu saja sangat sehat dan positif. Singkat kata, berbeda dengan pengalaman proses modernisasi dibanyak negara Barat. Disana, terjadi proses sekularisasi dan penyingkiran agama dalam kehidupan publik, sebaliknya di Indonesia pembangunan justru menghasilkan gairah dan kesetiaan pada agama. Dengan kian baiknya ekonomi masyarakat, semakin banyak pula dibangun rumah-rumah ibadah, atau semakin banyak pula orang yang menunaikan ibadah haji.

\section{Menggagas Pendidikan Islam yang Ideal}

Dengan mempertimbangkan semua perkembangan dan dinamika masyarakat itu, sistem pendidikan Islam akan berorientasi pada pembinaan dan nilai-nilai agama dalam diri anak. Sistem pendidikan Islam harus memenuhi dua tantangan pokok. Ptrkama, penguasaan ilmu pengetahuan dan teknologi; dan kedua, penanaman pemahaman dan pengamalan ajaran agama. Keduaduanya harus dilakukan secara integral, humanistik, pragmatik, dengan memperlihatkan budaya lokal dan didasarkan kepada nilai-nilai religiusitas. 
Hanya dengan cara ini pendidikan Islam bisa fungsional di tengah-tengah masyarakat dalam menyiapkan dan membina sumberdaya manusia masa depan seutuhnya. Dengan cara ini, pengentasan kemiskinan dapat dilakukan secara bertahap, namun pasti.

Berdasarkan pertimbangan tersebut, pendidikan Islam diharapkan mampu menjadi pendidikan yang ideal, yaitu pendidikan yang integralistik, humanistik, pragmatik, dan berakar kuat. Pertama, pendidikan yang integralistik mengandung komponen-komponen kehidupan yang meliputi Tuhan, manusia dan alam sebagai sesuatu yang integral.

Pendidikan yang integralistik diharapkan bisa menghasilkan manusia yang memiliki integritas tinggi, yang bisa bersyukur dan manyatu dengan kehendak Tuhan, yang bisa menyatu dengan dirinya sendiri (sehingga tidak memiliki keperibadian terbelah), menyatu dengan masyarakat (schingga bisa menghilangkan disintegrasi sosial), dan bisa menyatu dengan alam (sehingga tidak membuat kenusakan).

Kedua, pendidikan yang humanistik memandang manusia sebagai makhluk, yakni makhluk ciptaan Tuhan dengan fitrah-fitrah tertentu. Sebagai makhluk hidup, ia harus melangsungkan, mempertahankan, dan mengembangkan hidup. Sebagai makhluk batas - antara hewan dan malaikat - ia menghargai hak-hak asasi manusia, seperti hak untuk berlaku dan diperlakukan dengan adil, hak menyuarakan kebenaran, hak untuk berbuat kasih sayang, dan sebagainya.

Pendidikan humanistik diharapkan dapat mengembalikan hati manusia di tempat semula dengan mengembalikan manusia kepada fitrahnya sebagai makhluk. Manusia "yang manusiawi" yang dihasilkan oleh pendidikan yang humanistik diharapkan bisa berpikir, berasa, berkemauan, dan bertindak sesuai dengan nilai-nilai luhur kemanusiaan yang bisa mengganti sifat individualistik egoistik, egosentrik, dengan sifat kasih sayang kepada sesama manusia, sifat ingin memberi dan menerima, sifat saling menolong, sifat mencari kesamaan, dan sebagainya.

Ketiga, pendidikan yang pragmatik adalah pendidikan yang memandang manusia sebagai makhluk hidup selalu membutuhkan sesuatu untuk melangsungkan, mempertahankan dan mengembangkan hidupnya, baik bersifat jasmani, ruhani maupun sukmawi. Pendidikan "pragmatik" diharapkan dapat 
mencetak manusia "pragmatik" yang sadar pada kebutuhan-kebutuhan hidupnya, peka terhadap masalah-masalah kemanusiaan dan dapat membedakan manusia dari kondisi dan situasi yang tidak manusiawi.

Kempat, pendidikan yang berakar pada budaya kuat, yaitu pendidikan yang meninggalkan akar-akar sejarah kebudayaan suatu bangsa atau kelompok etnis. Pendidikan yang berakar budaya kuat diharapkan dapat membentuk manusia yang mempunyai keperibadian, harga diri, percaya pada diri sendiri, dan membangun peradaban berdasarkan budayanya sendiri.

\section{Penutup}

Sebagai pendidikan yang ideal, sistem pendidikan Islam diharapkan dapat mengintegrasikan nilai-nilai ilmu pengetahuan, nilai agama dan teknik, sehingga mampu melahirkan manusia yang cerdas, berpengetahuan, sebagai realisasi dari adanya relasi vertikal-horisontal dengan nilai-nilai ilahiyah. Dengan demikian, pendidikan Islam diharapkan menjadi wahana yang strategis bagi upaya peningkatan mutu kehidupan dengan terbentuknya pilihan untuk kesempatan mengembangkan diri dari masa depan. Pendidikan memiliki peran sentral dalam proses mendorong individu untuk mencapai kemajuan pada aspek kehidupan yang didasarkan pada nilai-nilai ajaran Islam.

Langkah awal yang harus dilakukan dengan mengadakan perubahan pendidkan adalah merumuskan kerangka dasar filosofis yang sesuai dengan ajaran Islam, kemudian mengembangkan teori pendidikan yang didasarkan pada asumsi-asumsi dasar tentang manusia dan hubungannya dengan masyarakat, lingkungan, dan ajaran Islam. Tanpa hal itu, maka pembaruan pendidikan Islam tidak akan mempunyai pondasi kuat dan arah yang pasti. Kerangka dasar filosofis harus ditempatkan dalam konteks suprasistem diterapkannya pendidikan.

\section{Endnotes}

${ }^{1}$ M. Natsir, Kapita Selecto (Jakarta: Bulan Bintang, 1973), hal. 77.

${ }^{2}$ Selo Soemarjan dan Soelaeman Soemardi, Serangkai Bunga Sosiologi (Jakarta: FE UI, 1974). 

75-81.

${ }^{3}$ Lihat A. Malik Fajar, Reorientosi Pendidikan Islam (Jakarta: Fajar Dunia, 1999), haL.

4Ace Suryadi dan H.A.R. Tilaar, Analisis Kebijakan Pendidikan: Suatu Pengantar (Bandung Remaja Rosdakarya, 1993).

${ }^{5}$ M. Franscis Abram, Perspective on Modemization: Fonward a General Theology of Thind World Development (University Press America, 1980).

${ }^{6}$ Malik Fajar, Reorientasi..., hal. 77.

'Suyanto dan Djihan Hasyim, Refleksi Agenda Reformasi Pendidikan di Indonesia Memosuki Milenuim III (Yogyakarta: Adicipta Karya Nusa, 2000) hal. 22.

'H.A.R. Tilaar Beberapa Agenda Reformasi Pendidikan Nasional Dalam Perspektif Abad 21 (Magelang: Indonesia Tera, 1998), hal. 26.

'Ibid.

12 H.M. Bambang Purwo, "Reformasi Pendidikan Islam dalam Milenium III", dalam Mudja Rahardjo, Quo Vadis Pendidikan Islam: Pembacaan Realistis Pendidikan Islam Sosial dan Pengetahuan (Malang: Cendekia Putra Mulya, 2002) haL. 92.

${ }^{11}$ Muhaimin, et al. Paradigma Pendidikan Islam Upaya Mengefektifkan Pendidikan Agama Islam di Sekolah (Bandung: Remaja Rosdakarya, 2001), hal. 92.

R2 Azyumardi Azra, Pendidikan Islam: Tradisi dan Modermisasi Menuju Milenium Baru (Jakarta: Logos, 1999), hal. 59.

${ }^{13}$ M. Rusli Karim, "Pendidikan Islam di Indonesia dalam Transformasi Sosial Budaya", dalam Muslih Usa (Ed.), Pendidikan Islam di Indonesia Antara Cita dan Fakta (Yogyakarta: Tiara Wacana, 1991), hal. 129.

${ }^{14}$ Azyumardi Azra, Pendidikan Islam.

${ }^{15}$ Ibid., hal. 57.

${ }^{15}$ Ibid., hal. 58.

\section{Daftar Pustaka}

Abram, M. Franscis. 1980. Perspective on Modermization: Forward a General Theology of Third World Development. Amerika: University Press America.

Azra, Azyumardi. 1999. Pendidikan Islam: Tradisi dan Modermisasi Menuju Milenium Baru. Jakarta: Logos.

Fajar, A. Malik. 1999. Reorientasi Pendidikan Islam. Jakarta: Fajar Dunia.

Karim, M. Rusti. 1991. "Pendidikan Islam di Indonesia dalam Transformasi Sosial Budaya", dalam Muslih Usa (Ed.). Pendidikan Islam di Indonesia Antara Cita dan Fakta. Yogyakarta: Tiara Wacana.

M. Natsir. 1973. Kapita Selecta. Jakarta: Bulan Bintang.

Muhaimin, et al. 2001. Paradigma Pendidikan Islam Upaya Mengefektifkan Pendidikan Agama Islam di Sekolah. Bandung: Remaja Rosdakarya. 
Purwo, H.M. Bambang. 2002. "Reformasi Pendidikan Islam dalam Milenium III", dalam Mudja Rahardjo. Quo Vadis Pendidikan Islam: Pembacaan Realistis Pendidikan Islam Sosial dan Pengetahuan. Malang: Cendekia Putra Mulya.

Soemarjan, Selo dan Soelaeman Soemardi. 1974. Serangkai Bunga Sosiologi. Jakarta: FE UI.

Suryadi, Ace dan H.A.R. Tilaar. 1993. Analisis Kebijakan Pendidikan: Suatu Pengantar. Bandung Remaja Rosdakarya.

Suyanto dan Djihan Hasyim. 2000. Refleksi Agenda Reformasi Pendidikan di Indonesia Memosuki Milenuim III. Yogyakarta: Adicipta Karya Nusa.

Tilaar, H.A.R. 1998. Beberapa Agenda Reformasi Pendidikan Nasional Dalam Perspektif Abad 21. Magelang: Indonesia Tera. 